\title{
Transposition
}

Musique et Sciences Sociales

9| 2021

Musique et sexualité

\section{Reflecting on Music and Erotic Agency: Sonic Resources and Socio-sexual action (Body \& Society 1997)}

Tia DeNora

\section{OpenEdition}

Journals

Electronic version

URL: http://journals.openedition.org/transposition/6268

DOI: $10.4000 /$ transposition.6268

ISSN: $2110-6134$

Publisher

CRAL - Centre de recherche sur les arts et le langage

\section{Electronic reference}

Tia DeNora, "Reflecting on Music and Erotic Agency: Sonic Resources and Socio-sexual action (Body \& Society 1997)", Transposition [Online], 9 | 2021, Online since 30 March 2021, connection on 23 April 2021. URL: http://journals.openedition.org/transposition/6268 ; DOl: https://doi.org/10.4000/ transposition. 6268

This text was automatically generated on 23 April 2021.

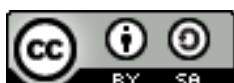

La revue Transposition est mise à disposition selon les termes de la Licence Creative Commons Attribution - Partage dans les Mêmes Conditions 4.0 International. 


\title{
Reflecting on Music and Erotic Agency: Sonic Resources and Socio- sexual action (Body \& Society 1997)
}

\author{
Tia DeNora
}

1 It is nice to be invited to reflect on this essay. Thank you to the editors for the invitation. I am especially pleased to be appearing in Transposition along with Annegret Fauser and the other authors.

2 This was a piece I published the year I began the research for Music in Everyday Life (DeNora 2000). I was a much younger scholar (and woman), it was a particular "moment" circa 1995, and I was teaching a final year course on gendered bodies. I thought the Goffmanian perspective applied to sexual conduct would be good to think with - if you wanted to think about the nexus of culture and biology. But I also thought that Goffman did not take us far enough into the topic.

What I had in mind was that a concern with "impression management" and, more broadly, dramaturgy (the performative features of action, including physical action) could have been more explicitly linked to the interdisciplinary study of physical and physiological embodied processes. That would have involved examining the different forms of bio-feedback and mutual constitution that are, or may be, involved when we "dramatize". Dramaturgy involves orienting to cultural materials such as imagined/ learned scripts or imagery. It also involves often tacit understandings of how types of action might, or should, be "choreographed" in real time. How then does cultural practice literally get incorporated?

4 I suppose that question was one that followed on from Iris Young's famous essay, "Throwing Like a Girl" (Young 1980). And the concern with incorporation [DeNora $2000]$ is one I have since investigated in relation to music, pain management and the socalled, "placebo effect" [DeNora 2013; DeNora 2014] and in ongoing collaborative research as part of the Care for Music project.)

5 At the time I wrote the Body \& Society piece, I had recently completed the key publication arising from a study of the cervical mucus method of contraception/ 
fertility awareness (DeNora 1996). I was beginning to work on historical studies of (a) the interaction between science, music and emerging notions of gender difference and (b) gendered comportment and keyboard performance, both in Vienna circa 1780-1800 (DeNora 1997 and 2002). So, it was a heady time for studies of the body for me, and also, I think, for many people. I was reading and learning a lot from the work of Stevi Jackson (as referred to in the original article) and later interacting with Stevi Jackson and Sue Scott in relation to their study of acting in sexual situations (Jackson and Scott 2007). In addition, my colleague Robert Witkin had recently drafted an essay which was then, I confess, beyond my ability to comprehend it (some of the ideas later appeared in [Witkin 1995]), and which I do not think he has ever published. It was entitled something like, "Muscular and Glandular Epistemologies" and in my opinion he should try to publish it now because, with hindsight, I think of it as pioneering. It pointed to later sociological perspectives on embodied cognition and affect to be sure. Some of what Witkin had to say in that essay and in his other publications also inspired Sophia Acord's research on embodied cognition in the work of world-class art curators (Acord 2016; Acord and DeNora 2008).

6 So, lots of things came together that helped me, circa 1996, to think about where to go next, socio-musically speaking, in relation to embodiment, music and affect. Thinking about this article, I remember being struck, while preparing it, that whenever I gave a talk on the topic (seminars for LAMS, Milano, and Brussels for the ISA Sociology of Arts meeting) I was offered many more tales, from - mostly - women about the role of music in their intimate, sexual lives. For me this was less about the sociology of sexuality and more about the grounded theory of how culture - and particularly non-propositional, non-representative forms of culture (which music is, at least some of the time) can be understood - and observed to - get into action. The topic was also taken up around 1997 by Dana Wilson-Kovacs, who has since published around her research on intimate culture (Wilson-Kovacs 2012).

7 And this took me into a kind of critique-of-the-critique of interactionist sociologies. Too many times interactionism is accused of ignoring the so-called, "big picture" structure, constraint, history. By contrast, to my mind, what is really interesting is how these things enter into action as resources, and indeed are themselves instantiated or "made real" in and through how they are invoked. In other words, structures exist, but only become manifest when we recognise them in our acts. Structure - norms, conventions, scripts, expectations, rules - is known to us in and through what happens in real time enactments. So how are gendered notions of embodiment enacted in real time? That question highlights the indexical features of all culture - how is culture, in this case, literally "fleshed out" in and through meaningful symbolic interaction? We need to look at where the action is...

Another theoretical motive in writing the paper was to consider something then perhaps unfashionable (because of how it could be mistaken for biological determinism) - the idea that the Nature/Culture nexus does not need to imply that all of the natural realm is "mere" culture. Rather, how might we examine our physical, embodied realities as they take shape in relation to meanings, practices and conventions but also shape those meanings? The theorist at the time who seemed to say this mostly clearly, as far as I was concerned, was Lynda Birke (1999), trained as both biologist and sociologist (and I recall a tête-à-tête meal in the local spaghetti house after her Centre for Women's Studies seminar where we discussed some of these issues 
at some length - and over a healthy amount of red wine!). Science and Technology studies just seemed to "get" these things and it's perhaps not surprising that I also learned a great deal, beginning in the 1990s, from Antoine Hennion and his particular vision of attachment (Hennion 2007). Thus, the idea, in the Body \& Society piece, was (as I put it at the time) - the nature/culture relationship is at once too tight and too loose: It is too tight insofar as action, and embodied features, can escape discursive constructions - bodies bleed and ooze for example no matter how they are represented. It is too loose because bodies also become and change in relation to discursive constructions - as in the placebo effect, as in erotic response. Which returns us to how, in my view, the Goffmanian perspective did not go far enough.

9 To me, at the time, the really interesting question was one that examined the culture/ nature and culture/action relationships in real - and often micro - time and real situations and scenes. It was a question oriented to how fragments of culture, molecules of meaning or semiotic fragments, often reworked or misheard/ misunderstood (creatively appropriated, in other words, they can propel our actions, and our embodied processes forward (or backward). Music seemed like a good thing to think with for this project because of the ways it can actually be seen to linger, or hang around in, bodies and in ways that show up as embodied processes of movement, comportment and stylistic orientation and because of course, through the ways it models, or makes, time (Ansdell 2014). These days, in our Care for Music project, the team is looking at this question in relation to community music therapy and in scenes of late life, and from the perspective of embodied cognitive processes. These processes can, even in situations where profound dementia plays a part, be relied upon to quicken actors and actions and in ways that forge connection and bonding, and generate pleasure, meaning, and joy - and reorganise embodiment, sometimes within a second. Not always, of course (and sometimes not for the better) but in all cases the question remains: how does culture get in to action and facilitate social situations, encounters - and embodiment (s)?

\section{BIBLIOGRAPHY}

ACORD Sophia Krzys, «Feeling and thinking in art curation: Grounds for a relational aesthetic for sociology? », SAVAGE Mike, HANQUINET Laurie, Handbook of the Sociology of Art and Culture, London, Routledge, 2016, p. 219-231.

ACORD Sophia Krzys, DENORA Tia, «Culture and the Arts: From Art Worlds to Arts in Action », Annals of the American Acaemcy of Political and Social Science, vol. 619, 2008, p. 223-237.

ANSDELL Gary, How Music Helps: in music therapy and everyday life, London, Routledge, 2014.

BIRKE Lynda, Feminism and the Biological Body. Edinburgh, Edinburgh University Press, 1999.

DENORA Tia, «From physiology to feminism: reconfiguring body, gender and expertise in natural fertility control », International Sociology 11, vol. 3, 1996, p. 359-383. 
DENORA Tia, « The Biology Lessons of Opera Buffa », HUNTER M. WEBSTER J. (eds.), Opera Buffa in Mozart's Vienna, Cambridge, Cambridge University Press, 1997, p. 146-164.

DENORA Tia, Music in Everyday Life. Cambridge, Cambridge University Press, 2000.

DENORA Tia, « Music into action: Performing gender on the viennese concert stage, 1790-1810 », Poetics, 30 (1-2): 19-33, 2002.

DENORA Tia, Music Asylums: Wellbeing through music in everyday life, London, Ashgate, 2013.

DENORA Tia, Making Sense of Reality, London, Sage, 2014.

HENNION Antoine, « These Things That Hold Us Together », Cultural Sociology 1, 1: 97-114, 2007.

WITKIN Robert, Art and Social Structure, Cambridge, Polity Press, 1995.

WILSON-KOVACS Dana, « Consumption and sexual intimacy: Towards an understanding of intimate cultures in everyday life ", Gender and Consumption: Domestic Cultures and the Commercialisation of Everyday Life, London, Routledge, 2017 [2007], p. 181-196.

YoUNG Iris, «Throwing Like a Girl: A Phenomenology of Feminine Body Comportment, Motility and Spaciality ", Human Studies, 3: 2, 1980, p. 137-156.

\section{AUTHOR}

\section{TIA DENORA}

Tia DeNora's initial studies were in music and sociology at West Chester University in Southeastern Pennsylvania. She completed her PhD in Sociology in 1989 at the University of California San Diego. From then until 1992, she worked at University of Wales Cardiff (where she was a University of Wales Fellow from 1989-91). She moved to Exeter in 1992 where she is currently Professor of Socioogy of Music. DeNora has been a Fellow of the Yale Center for Cultural Sociology since 2004 and recently was elected Fellow of the British Academy. She has served as Chair of the ESA Network on Arts Sociology and on various councils of learned societies, editorial boards and the 2008/2014 national Research Excellence Framework sub-panel for Sociology. With Gary Ansdell, she currently co-edits the Routledge Series on Music \& Change: Ecological Perspectives. Her publications include Beethoven and the construction of genius: musical politics in Vienna 1792-1803 (University of California Press, 1995), Music in everyday life (Cambridge University Press, 2000), After Adorno: rethinking music sociology (Cambridge University Press, 2003), Music-in-action: essays in sonic ecology (Ashgate, 2011), Music asylums: wellbeing through music in everyday life (Ashgate, 2013), and Making sense of reality: culture and perception in everyday life (Sage, 2014). 